Studia Oecumenica 17 (2017)

DOI: $10.25167 / \mathrm{SOe} / 17 / 2017 / 221-231$

JANUSZ PODZIELNY

Wydział Teologiczny UO

\title{
Praca jako powolanie. Istotne elementy luterańskiego etosu pracy
}

\author{
Work as Vocation. The Significant Elements of Lutheran Ethos of Work
}

\begin{abstract}
The aim of this paper is to look at the specifics of the Lutheran approach to the human labour, which often is described as vocation. The article is divided into three parts: (1) Freedom as essence of Luther's ethics; (2) Luther's views on the work; (3) Today's symptoms of Lutheran ethos of work. The conclusions framed in this study are as follows. Lutheran ethos of work, although it strongly emphasizes the need of work and diligence, doesn't recognize the person as homo laborens only, i.e. a being realizing himself exclusively by the work. The human labour should be considered as a honourable duty, service to the neighbours, and has to be seen also as a vocation and source of joy. However, the work cannot be the only a form of human activity. Because both workaholism and laziness are sinful, inappropriate and harmful behaviours. The quintessence of this Evangelical-Lutheran approach to the phenomenon of human labour is therefore the healthy attitude to him, and the right place, which the work should occupy in the daily life of a Christian, so that he could responsibly enjoy the gift of freedom.
\end{abstract}

Keywords: human labour, vocation, freedom, responsibility, ethos of work, Lutheran ethics.

\section{Streszczenie}

Celem niniejszego artykułu jest przybliżenie specyfiki luterańskiego podejścia do pracy człowieka, gdzie najczęściej jest ona traktowana jako powołanie. Tekst ten składa się z trzech zasadniczych punktów, w których: po pierwsze, przypomniano poglądy samego Ojca Reformacji na temat istoty etyki; po drugie, przybliżono refleksje Lutra odnośnie do pracy i ludzkiej pracowitości; po trzecie zaś, omówiono współczesne odniesienia dotyczące luterańskiego etosu pracy. Reasumując, należy podkreślić, iż etos pracy, ukształtowany przez Marcina Lutra oraz jego następców, mimo iż akcentuje potrzebę ludzkiej aktywności, to jednak nie ujmuje człowieka jedynie jako istoty realizującej się poprzez działalność zawodową (homo laborens). Praca jest tu uważana za zaszczytny obowiązek, służbę na rzecz innych, a także powołanie i źródło radości. Kwintesencją ewangelicko-luterańskiego podejścia do fenomenu pracy jest zatem właściwe miejsce, jakie winna ona zajmować w życiu chrześcijanina, tak aby mógł on odpowiedzialnie korzystać z daru wolności. 
Słowa kluczowe: praca ludzka, powołanie, wolność, odpowiedzialność, etos pracy, etyka luterańska.

Etos pracy stanowi z całą pewnością jedną z ważniejszych cech luterańskiej, czy też mówiąc szerzej - ewangelickiej tożsamości. W potocznej świadomości często etyka ewangelicka sprowadzana jest właśnie do etosu pracy. Wynika to w dużej mierze z upowszechnienia tez wydanej w 1905 r. przez niemieckiego socjologa, prawnika i ekonomistę Maxa Webera (1864-1920) książki pt. Die protestantische Ethik und der Geist des Kapitalismus ${ }^{1}$. Jej autor rozpoczął swoje wywody od pewnej obserwacji współczesnych mu zjawisk. Mianowicie zauważył, iż w krajach, gdzie obecni są zarówno protestanci, jak i katolicy, proporcjonalnie więcej menadżerów, posiadaczy kapitału, a także wykwalifikowanych techników i pracowników administracji bywa wśród protestantów. Na podstawie tego Weber dokonał pewnej rekonstrukcji etosu protestanckiego, odwołując się zwłaszcza do życia codziennego purytanów, kalwinów w XVIII i XIX w. W pracy tego niemieckiego socjologa można odnaleźć tezę, iż duchowość protestancka, szczególnie zaś swego rodzaju asceza wewnątrzświatowa oraz pojmowanie pracy jako powołania, stały się mechanizmami napędowymi nowożytnego kapitalizmu².

Celem niniejszego artykułu nie jest analiza poglądów socjologicznych i ekonomicznych Maxa Webera, z którymi, co warto podkreślić, wielu historyków ekonomii do dziś się nie zgadza ${ }^{3}$. Chodzi bardziej o przyjrzenie się, także z racji przeżywanego obecnie 500-lecia Reformacji, owej specyfice luterańskiego podejścia do pracy człowieka, gdzie najczęściej jest ona traktowana jako powołanie. Warto w tym kontekście przypomnieć wpierw poglądy samego Ojca

1 Por. M. Weber, Etyka protestancka i duch kapitalizmu, Lublin 1994.

${ }^{2}$ Max Weber wymieniał w tym kontekście przede wszystkim kalwinów oraz członków radyklanych, ascetycznych grup protestanckich. Przykładowo nawiązywał do wypowiedzi Johna Wesleya (1703-1791), współzałożyciela Kościoła metodystycznego, który nakłaniał wszystkich chrześcijan do zarabiania i oszczędzania, ile tylko się da, czyli po prostu do bogacenia się. Osiąganie dużego majątku świadczyło bowiem o sprzyjaniu przez Pana Boga. Por. M. Hintz, Teologiczne aspekty ewangelickiego etosu pracy, „Gdański Rocznik Ewangelicki” 3 (2009), 29-30; J. GARDAWSKI, Ewangelicki etos pracy a efektywność makroekonomiczna, „Gdański Rocznik Ewangelicki” 3 (2009), 13-16.

${ }^{3}$ Pojawiają się przykładowo stwierdzenia, iż etyka protestancka była wprawdzie ważnym motywem rozkwitu kapitalizmu w krajach, gdzie szerzej rozpowszechniła się Reformacja, jednak to nie znaczy, że geneza ducha kapitalizmu leży poza teologią katolicką. Pewne ważne formy kapitalistycznego przedsiębiorstwa są bowiem o wiele starsze od Reformacji. Należy tu choćby wspomnieć o refleksji scholastycznych teologów o pożyczaniu na procent, handlu, wymianie i sprawiedliwej cenie. Zdaniem wielu, właśnie średniowieczna szkoła franciszkańska przyczyniła się znacząco do wytworzenia podstawowych kategorii zachodniej myśli ekonomicznej. Por. A. FANFANI, Cattolicesimo e protestantesimo nella formazione storica del capitalismo, Milano 1934; M. NovaK, Duch demokratycznego kapitalizmu, Poznań 2001; O. BAzzichI, Alle radici del capitalismo. Medioevo e scienza economica, Cantalupa 2003; S. SABATInI, Etyka i ekonomia po Weberze, „Społeczeństwo” $20(2010) \mathrm{nr} 6,832-835$. 
Reformacji na temat istoty etyki oraz pracy i ludzkiej pracowitości, aby później omówić współczesne odniesienia, gdy idzie o luterański etos pracy.

\section{Wolność jako istota etyki Lutra}

Reformator z Wittenbergi, Marcin Luter (1483-1546), dokonał pierwszej prezentacji swych poglądów etycznych w piśmie z 1520 r. pt. $O$ wolności chrześcijańskiej (De libertate christiana). Oczywiście, trudno znaleźć w tym niewielkim dziele jakiś spójny wykład na temat pracy, jednak zawarte w nim niektóre spostrzeżenia Ojca Reformacji wskazują na istotne także do dzisiaj cechy luterańskiego etosu pracy. Centralną tezę owego traktatu stanowią słowa: „Chrześcijanin jest całkowicie wolnym panem wszystkich rzeczy, nikomu niepodległym” oraz „Chrześcijanin jest najuleglejszym sługą wszystkich rzeczy i wszystkim podległy"4.

Pierwsza część tego stwierdzenia Marcina Lutra oznacza, według ewangelików, iż będąc uczniem Chrystusa, chrześcijanin jest wolny od zewnętrznych przykazań i obyczajów, w tym również od pobożności oraz przepisów kościelnych. Dla człowieka duchowego żadna zewnętrzna rzecz nie ma więc najmniejszego znaczenia, gdyż do życia, sprawiedliwości i wolności chrześcijańskiej potrzeba jedynie nieskażonego Słowa Bożego, Ewangelii Chrystusowej. Ewangelia ma bowiem moc wyzwalającą grzesznika. W Chrystusie zaś osiąga się pełnię wolności. Do niepotrzebnego jarzma uczynków Luter zaliczał m.in. źle pojętą ascezę czy też obrzędy oraz ceremonie kościelne, które - jego zdaniem winno się traktować podobnie jak „u rzemieślników traktuje się owo rusztowanie

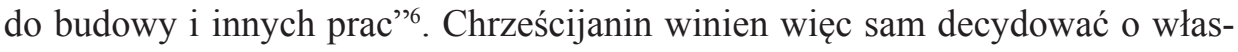
nym życiu oraz kształtować je na miarę swej wolności i powołania7.

Druga część sformułowania Ojca Reformacji na temat ludzkiej wolności dotyczy wezwania wyzwolonego chrześcijanina do działania. Człowiek bowiem w tym celu staje się wolny od przymusów i ograniczeń, aby swoim życiem i pracą, rozumianą jako służba bliźniemu, wielbić Boga. Jest to zatem wolność

${ }^{4}$ M. LuTER, O wolności chrześcijańskiej (1520), http://old.luteranie.pl/www/biblioteka/dpisma/luter3.htm (16.01.2017).

5 Por. tamże.

${ }^{6}$ Tamże; por. M. Hintz, Teologiczne aspekty ewangelickiego etosu pracy, 36; M.J. UGLoRz, Ewangelicki etos pracy w kontekście integralnie pojmowanej ekonomii, http://naszedziedzictwo. blox.pl/2012/11/Ewangelicki-etos-pracy-w-kontekscie-integralnie-1.html (16.01.2017).

${ }^{7}$ Być może również z tego powodu wynika tak niewielka ilość praktyk religijnych wśród protestantów. Przykładowo w Niemczech w 2014 r. na niedzielne nabożeństwa uczęszczało tylko 3,3\% ewangelików. Por. EKD-Statistik. Gottesdienst und Abendmahl, https://www.ekd.de/statistik/ gottesdienst.html (16.01.2017). 
ku czemuś, ku działaniu, ku służbie, która stanowi wyróżnik wolności chrześcijańskiej. Takie relacyjne ujęcie wolności u Lutra sprzeciwia się pasywności, jaka była nieraz obserwowana w różnych nurtach duchowości chrześcijańskiej (np. w kwietyzmie). Chrześcijanin, według reformacyjnej koncepcji, to zatem człowiek aktywnie żyjący (niem. Weltperson), odpowiedzialny nie tylko za własne życie religijne, lecz również za kształt tego świata. Podejmuje on problemy świata doczesnego w myśl zasady, która później stała się jednym z głównych haseł ewangelicko-luterańskiej etyki: „Wiara jest skuteczna przez miłośc”” (fides per charitatem efficax). Jako osoba przynależąca do Boga, człowiek zostaje obdarzony duchową wolnością, ale zarazem jako osoba pozostająca w świecie, jest zobowiązany do miłości i miłosierdzia, oraz w tym sensie staje się symbolicznym sługą spraw tego świata. Zgodnie z postulatami Lutra, człowiek jawi się więc jako istota, która spełnia się z jednej strony w religijnej relacji do Boga, $\mathrm{z}$ drugiej zaś - w etycznym działaniu wobec bliźniego ${ }^{8}$.

\section{Poglądy Ojca Reformacji na temat pracy}

Ważne miejsce w etyce gospodarczej Reformatora $\mathrm{z}$ Wittenbergi zajmuje kwestia pojmowania pracy, zawodu jako powołania (niem. Beruf als Berufung). Temat ten stanowi, zdaniem wielu, najważniejszy teologiczny aspekt ewangelickiego etosu pracy aż po dzień dzisiejszy9 . Za sprawą Marcina Lutra znana benedyktyńska formuła: „Módl się i pracuj” (ora et labora) została zastąpiona w tradycji ewangelickiej sformułowaniami: „Módl się, pracując” bądź „Módl się poprzez pracę" (ora laborens). W ten sposób praca została potraktowana wręcz jako modlitwa, jako wyraz chwały Bożej. Można więc mówić o swoistej sakralizacji codziennej pracy w luteranizmie. Bóg bowiem uświęca każdy rodzaj odpowiedzialnie wykonywanej pracy oraz z perspektywy godności zrównuje poszczególne zawody. Oznacza to, że każda praca, która nie sprzeciwia się Słowu Bożemu, posiada w sobie wartość transcendentną. Należy nie tylko do porządku świata, ale także do Bożego powołania. Konsekwencją takich poglądów jest właśnie ów luterański - czy też ujmując szerzej - ewangelicki etos pracy, którego ważnym fundamentem jest nowa relacja do podejmowanej przez człowieka pracy. Zawodowa aktywność jawi się odtąd nie jako przejaw kary czy przekleństwa,

${ }^{8}$ Por. M. Hintz, Teologiczne aspekty ewangelickiego etosu pracy, 36-37; M.J. UGLORZ, Ewangelicki etos pracy; B. MiLERSKI, Etos pracy jako postać świadomości protestanckiej, „Gdański Rocznik Ewangelicki” 3 (2009), 60-62.

9 Por. A. Pawlas, Die lutherische Berufs- und Wirtschaftsethik. Eine Einführung, Neukirchen-Vluyn 2000, 15-83; N.O. Oermann, Anständig Geld verdienen? Eine protestantische Wirtschaftsethik, Freiburg im Br. 2014, 111-112; W. HUBER, Ethik. Die Grundfragen unseres Lebens von der Geburt bis zum Tod, München 2016, 146-148. 
lecz jako dar Boga, umożliwiający pobożnemu i uczciwemu człowiekowi nadanie sensu swemu życiü ${ }^{10}$.

Koncepcja pracy jako powołania została sformułowana przez Marcina Lutra przede wszystkim w kontekście nauki o stworzeniu. Praca oraz odpoczynek to bowiem nakazy Boże, jak również wzajemnie uzupełniające się elementy ludzkiej egzystencji. Interpretując w Dużym Katechizmie III przykazanie Dekalogu, wittenberski Reformator podkreślał, że hebrajskie słowo šabbat znaczy „odpoczywać”, „wstrzymywać się od pracy”. Zdaniem Lutra, pierwotne znaczenie dnia szabatu jest nie tyle świąteczne, ile bardziej chodzi tu o odzyskanie sił, by nie słabnąć wskutek ciągłej pracy. Dopiero na drugim miejscu jest, w ujęciu Reformatora z Wittenbergi, ów religijny, kultyczny charakter dnia świątecznego. Luter akcentował przy tym, że nie może to być czas próżnowania czy lenistwa, lecz powinien to być zasadniczo dzień obcowania ze Słowem Bożym. Albowiem dzięki temu człowiek najlepiej regeneruje siły niezbędne do dalszej pracy: „Święcić dzień święty znaczy tyle, co święcie go zachować. (...) Nie w ten sposób, że się za piecem siedzi i nie wykonuje żadnej cięższej pracy, lub że się wieńcem stroi głowę i wdziewa najlepszą odzież, lecz (...) gdy zajmujemy się Słowem Bożym i ćwiczymy się w nim"11.

Pojmowanie pracy i zawodu jako powołania Ojciec Reformacji uzasadniał również wiarą w Bożą Opatrzność. W imię tej wiary całkowite posłuszeństwo Panu Bogu wyraża się w bezwarunkowej akceptacji takiego miejsca w życiu człowieka, jakie zostało mu dane przez Boga. W swoim zawodzie człowiek jest bowiem Bożym narzędziem, a nawet współpracownikiem, podobnie jak biblijny Adam był współpracownikiem Boga w ogrodzie Eden. Bóg powołał człowieka do pracy, ponieważ On sam pracuje. Praca staje się dzięki temu, według Lutra, prawdziwą radością i przyjemnością, gdyż człowiek stworzony jest do pracy, podobnie jak ptak do latania. Natomiast z powodu bezczynności i próżniactwa ludzie tracą wszystko ${ }^{12}$.

$Z$ tak rozumianym etosem pracy wiązał się również sformułowany przez Lutra oraz jego zwolenników postulat dyscypliny chrześcijańskiej w zakresie prowadzenia codziennego życia. Miał on głównie charakter pastoralnego napomnienia motywowanego biblijnie. W jednej z najważniejszych ksiąg wyznaniowych lu-

${ }^{10}$ Por. M. Hintz, Marcin Luter - ojciec etyki ewangelickiej, w: M. Luter, Pisma etyczne, M. Hintz (red.), Bielsko-Biała 2009, 21; J. Gardawski, Ewangelicki etos pracy, 14; M.J. Uglorz, Ewangelicki etos pracy; B. MiLERSKI, Etos pracy jako postać świadomości protestanckiej, 64-65; A. Pawlas, Die lutherische Berufs- und Wirtschaftsethik, 118-119.

${ }^{11}$ M. Luter, Duży katechizm (1529), w: Księgi Wyznaniowe Kościoła Luterańskiego, Bielsko-Biała 2003, 70; por. M. HINTZ, Teologiczne aspekty ewangelickiego etosu pracy, 41.

${ }_{12}$ Por. M. Luter, Tessaradecas consolatoria pro laborantibus et oneratis (1520), https://archive.org/stream/werkekritischege06luthuoft\#page/120/mode/2up (16.01.2017); M.J. UGLORZ, Ewangelicki etos pracy. 
teranizmu, czyli w Wyznaniu augsburskim można bowiem przeczytać, iż „każdy chrześcijanin powinien się tak pilnować i trzymać w karbach przy pomocy karności cielesnej lub ćwiczeń cielesnych oraz pracy, aby dostatek lub próżność nie wiodły go do grzechu. (...) Paweł mówi: «Umartwiam ciało moje i ujarzmiam» (1 Kor 9,27). Wynika stąd jasno, że umartwia swe ciało nie po to, aby przez tę karność wysłużyć odpuszczenie grzechów, lecz aby utrzymać ciało w gotowości i zdatności do rzeczy duchowych i do wypełnienia obowiązków swego powołania"13. Życie zdyscyplinowane, legitymizowane motywami religijnymi, sprzyjało oczywiście przedsiębiorczości oraz sukcesom zawodowym, co odczytywane było jako realizacja Bożego powołania ${ }^{14}$.

Praca jawi się zatem u Marcina Lutra jako realizacja jednego z Bożych powołań. Wykonywanie pracy wpisane jest w ład społeczny. Jest ona jednym z istotnych wymiarów człowieczeństwa. Wynika z tego, zdaniem Ojca Reformacji, iż nie ma pracy lepszej albo gorszej. Każdą pracę należy spełniać z należytym zaangażowaniem, poświęceniem, wręcz pasją, gdyż w ten sposób człowiek może realizować Boży nakaz miłości bliźniego, pomagając innym. Praca bowiem dla Lutra to w sposób szczególny służba na rzecz bliźnich, służba społeczna: „Tak bowiem nakazuje apostoł, abyśmy rękami pracowali (Ef 4,28), by móc dawać temu, który jest w potrzebie. (...) Albowiem chrześcijańska to rzecz troska o zdrowie cielesne, abyśmy dzięki niemu mogli pracować, dorabiać się mienia, lecz zachować je na wspieranie potrzebujących. W ten sposób członek silny służyć będzie członkowi słabemu, wtedy staniemy się Synami Bożymi, wzajemnie o siebie troskliwymi i pracowitymi. Jedni drugich brzemiona nosząc, wypełniając w ten sposób zakon Chrystusowy - takie oto jest prawdziwe chrześcijańskie życie, taka jest miara prawdziwie skuteczna przez miłość, to znaczy z radością i miłością podejmująca dzieło najbardziej dobrowolnej niewoli, w której służy się drugiemu bezinteresownie, chętnie, opływając przy tym w pełnię i dostatek wiary"15.

Warto dodać, iż Reformator z Wittenbergi nie uważał, aby praca posiadała wartość samą w sobie. Kult pracy jest zatem nie do pogodzenia z etyką Lutra. Człowiek całkowicie oddający się pracy staje się bowiem jej niewolnikiem, tracąc z czasem swoje człowieczeństwo poprzez ubóstwianie pieniądza czy stanowiska ${ }^{16}$. Ojciec Reformacji w swej teologii i etyce starał się dowartościować

${ }^{13}$ F. Melanchton, Wyznanie augsburskie (1530), w: Księgi Wyznaniowe Kościoła Luterańskiego, Bielsko-Biała 2003, 155.

${ }^{14}$ Por. B. MilersKi, Etos pracy jako postać świadomości protestanckiej, 63-64.

${ }_{15}$ M. LuTER, O wolności chrześcijańskiej, por. M. HinTz, Teologiczne aspekty ewangelickiego etosu pracy, 41; A. Pawlas, Die lutherische Berufs- und Wirtschaftsethik, 47, 64.

${ }^{16}$ Swoisty kult pracy jako sposób walki ze złem tego świata pojawił się w innym nurcie protestantyzmu, zwłaszcza w XVII i XVIII w. w ruchach radykalnych, purytańskich, deprecjonujących 
wszystkie wymiary ludzkiego życia, będąc otwartym również na zabawy w gronie rodziny czy przyjaciół, muzykowanie oraz biesiady przy stole. W ten sposób Marcin Luter starał się łączyć pracę oraz wypoczynek, odnajdując właściwą proporcję w liczbie dni tygodnia, spośród których tylko jeden powinien być przeznaczony na przerwę $\mathrm{w}$ pracy ${ }^{17}$.

Wiele konkretnych porad z zakresu życia gospodarczego wittenberski Reformator zawarł w ramach głoszonych przez siebie kazań. Często podejmował zwłaszcza problematykę lichwy czy zniewolenia przez bogactwo, które też ostro piętnował ${ }^{18}$. Jeśli chodzi o jakieś ogólne wskazania dla pracujących, warto przywołać słowa z komentarzy biblijnych Marcina Lutra, gdzie wskazywał on, iż „Bóg nie chce leniwych próżniaków, przeto należy wiernie i pilnie pracować, każdy stosownie do swego zawodu. Do tego chce [Bóg] dodać błogosławieństwo i pomyślność"19. W innym tekście Ojciec Reformacji przypominał zaś, że ,pracować należy i trzeba, lecz pokarmu i dostatku domu nie powinno się przypisywać pracy, lecz dobroci i błogosławieństwu Boga. (...) Albowiem choćbyś sto lat orał i choćbyś wykonał wszelką pracę świata, nie mógłbyś jednak spowodować, aby choć jedno źdźbło wyrosło z ziemi, lecz wszystko to czyni Bóg (...)"20. Należy dodać, iż w swych kazaniach oraz innych pismach Luter krytykował też różne triki czy spekulacje, jakie stosowali ówcześni kupcy i bankierzy, chcąc się nieuczciwie wzbogacić. W centrum natomiast stawiał takie cnoty, jak: pilność, sumienność, skromność, uczciwość, solidarność społeczną, a także pobożność. Wszak, zdaniem Ojca Reformacji, „,należy tak pracować, jak gdybyśmy mieli żyć wiecznie, jednak tak usposobieni, jak byśmy mieli umrzeć jeszcze tej godziny"21.

cielesność i zmysłowość oraz głoszących konieczność ascezy wewnątrzświatowej. Por. M. HiNTz, Marcin Luter - ojciec etyki ewangelickiej, 22; W. HuBER, Ethik, 148-149.

${ }^{17}$ Por. M. Hintz, Teologiczne aspekty ewangelickiego etosu pracy, 42.

${ }^{18}$ Należy w tym kontekście wymienić następujące teksty Ojca Reformacji: Kleiner Sermon von dem Wucher (1519), https://archive.org/stream/werkekritischege06luthuoft\#page/2/mode/2up (16.01.2017); Großer Sermon von dem Wucher (1520), https://archive.org/stream/werkekritische ge06luthuoft\#page/36/mode/2up (16.01.2017); O kupiectwie i lichwie (1524), w: M. LutER, Pisma etyczne, M. Hintz (red.), Bielsko-Biała 2009, 161-178; An die Pfarrherrn wider den Wucher zu predigen (1540), https://archive.org/stream/werkekritischege51luthuoft\#page/324/mode/2up (16.01.2017).

19 M. Luter, Der 147. Psalm, Lauda Jerusalem, ausgelegt (1532), https://archive.org/stream/ werkekritischege3101luthuoft\#page/436/mode/2up (16.01.2017).

${ }^{20}$ TenżE, Der 127. Psalm ausgelegt an die Christen zu Riga in Ließland (1524), https://archive.org/stream/D.MartinLuthersWerkeWeimarerAusgabeWa15/Wa15\#page/n373/mode/2up (16.01.2017).

${ }_{21}$ TenżE, Viel fast nützlicher Punkt ausgezogen aus etlichen Predigten D. M. Luthers (1537), https://archive.org/stream/werkekritischege45luthuoft\#page/384/mode/2up (16.01.2017); por. M.J. UGLoRz, Ewangelicki etos pracy; M. HINTz, Teologiczne aspekty ewangelickiego etosu pracy, $37-40$. 


\section{Przejawy luterańskiego etosu pracy}

Etos pracy, jaki ukształtował się pod wpływem działalności Marcina Lutra, odznacza się dwiema zasadniczymi cechami. Jest to mianowicie połączenie pobożności z pracowitością. Pobożność stanowi tu formę uwielbienia Boga za dar zbawienia, natomiast pracowitość to nie smutna konieczność wynikająca z grzechu, ale prawdziwe powołanie, które nadaje sens ludzkiemu życiu. A zatem człowiek, w ujęciu etyki Lutra i jego następców, został stworzony do pracy, dlatego nie pracując, nie realizuje on w pełni swego człowieczeństwa ${ }^{22}$.

Skutki takiego sposobu myślenia oraz postępowania zaczęły być w sposób oczywisty w krótkim czasie widoczne. Przykładowo: sukcesy na polu rozwoju gospodarczego społeczeństw zachodniej i północnej Europy, które pozostają po dziś dzień w dużej mierze protestanckie, należy, zdaniem wielu, łączyć z panującymi w tych krajach zasadami wiary ewangelickiej. Za główną cnotę tradycyjnych mieszkańców tych państw uznaje się najczęściej sumienność czy też otwartość na pracę społecznie użyteczną, poprzez którą można służyć innym. Korzenie protestanckie są więc odnoszone do szeregu wartości składających się na: rzetelną pracę, uczciwość, wytrwałość, systematyczność, jak również odrzucenie tzw. podwójnej moralności, co prowadzi w konsekwencji do wzrostu zaufania między ludźmi. Zaufanie społeczne jest zaś mocno powiązane $\mathrm{z}$ efektywnością ekonomiczną (wzrostem PKB), gdyż skutkuje m.in. większą skłonnością do innowacji organizacyjnych, umiejętnością budowania układów sieciowych czy też tworzeniem wielkich transnarodowych korporacji. Z pewnością wiele przykładów tego typu działań można zauważyć w krajach dotkniętych wpływem Reformacji Marcina Lutra oraz jego zwolenników (np. w Niemczech, Szwajcarii, Holandii czy Anglii) ${ }^{23}$.

W Polsce żywotności luterańskiego etosu pracy można doświadczyć do dziś zwłaszcza na Śląsku Opolskim czy Cieszyńskim, gdzie poprzez wielowiekową obecność ewangelików ich etos pracowitości stał się też istotnym elementem śląskiej tożsamości. Odznacza się ona m.in. wielkim szacunkiem dla pracy człowieka, dbałością o jej jakość, jak również bezwzględnym wypełnianiem swoich obowiązków. W śląskim dialekcie można to streścić w sposób następujący: „tu trza robić” (tj. pracować), „robić swoji” (czyli to, co do każdego należy) oraz „dować pozór, jako sie robi" (a więc być uważnym, dokładnym), gdyż w przeciwnym razie traci się wszystko. Praca bowiem, poza życiową koniecznością, stała się w kontekście luterańskiego i śląskiego etosu także miarą wartości człowieka, codziennym spraw-

22 Por. M.J. Uglorz, Ewangelicki etos pracy.

${ }_{23}$ Por. B. MilersKi, Etos pracy jako postać świadomości protestanckiej, 65-67; J. GARDAWSKI, Ewangelicki etos pracy, 17-22. 
dzianem jego możliwości, co przejawia się zwłaszcza na wsi, np.: w stanie pól, w zapasie drewna opałowego, w postaci wyczyszczonych krów czy też posprzątanych zwłaszcza na niedzielę domostw. Każdy przechodzień może dzięki temu jednym spojrzeniem ocenić pracowitość (robotność), a zatem i wartość konkretnego gospodarza. Zamożnym, zgodnie z tym etosem, może być więc tylko człowiek pracowity (robotny), czyli, mówiąc inaczej: skromny, oszczędny, moralny, spolegliwy. Taką osobę powołuje się też najczęściej do przewodzenia innym - wśród sąsiadów lub w gminie (np. na stanowisko sołtysa czy wójta) ${ }^{24}$.

Jeśli zatem chodzi o najważniejsze cechy luterańskiego etosu pracy, obecne często po dzień dzisiejszy w śląskiej tożsamości, to warto podkreślić, iż:

- praca jawi się tutaj jako forma modlitwy, co oznacza, iż uczciwą pracą można służyć Bogu;

- niedziela stanowi dzień odpoczynku od pracy oraz dziękczynienia Stwórcy za jej dar;

- uczciwa praca winna zapewnić codzienny chleb oraz umożliwić człowiekowi godne życie.

Ewangelik, luteranin wierny przesłaniu Ojca Reformacji pracuje więc nie dlatego, że musi, ale ponieważ w ten sposób wypełnia swoje powołanie, nadając życiu sens poprzez służbę na rzecz innych. Zapłata jest tu oczekiwanym skutkiem pracy, jednak nie powinna być postrzegana jako cel sam w sobie ${ }^{25}$.

Podsumowując, należy zauważyć, że luterański etos pracy, mimo iż mocno akcentuje potrzebę pracy, pracowitości, to jednak nie ujmuje człowieka jedynie jako homo laborens, a więc jako istoty realizującej się wyłącznie poprzez aktywność zawodową. Praca winna być uważana za zaszczytny obowiązek, służbę na rzecz bliźniego, w końcu również za powołanie oraz źródło radości. Niemniej jednak nie może ona pozostawać jedyną formą ludzkiej działalności. Albowiem zarówno pracoholizm, jak i lenistwo to zachowania grzeszne, niewłaściwe, szkodzące człowiekowi. Kwintesencją ewangelicko-luterańskiego podejścia do fenomenu pracy jest zatem zdrowy do niej stosunek, właściwe miejsce, jakie praca winna zajmować w życiu codziennym chrześcijanina, tak aby mógł on odpowiedzialnie korzystać z daru wolności ${ }^{26}$. Wydaje się to dość interesujące

${ }^{24}$ Por. J. SzczePański, Korzeniami wrostem w ziemię, Ustroń 2003, 34-35; K. SzKaradniK, Wspólnota matego miasta a odpowiedzi(alność) wysztudyrowanych - wokót myśli i rodzinnych stron Jana Szczepańskiego, http://www.anthropos.us.edu.pl/anthropos10/texty/szkaradnik.htm (16.01.2017).

${ }_{25}$ Por. M.J. UGlorz, Ewangelicki etos pracy.

${ }^{26}$ Por. M. HinTz, Teologiczne aspekty ewangelickiego etosu pracy, 42-43. 
spojrzenie na pracę człowieka, które warto przypomnieć jako ważne dziedzictwo Reformacji w kontekście przeżywanej na całym świecie 500. rocznicy tego wydarzenia.

\section{Bibliografia}

BAzzichi O., Alle radici del capitalismo. Medioevo e scienza economica, Cantalupa 2003.

EKD-Statistik. Gottesdienst und Abendmahl, https://www.ekd.de/statistik/gottesdienst.html (06.01.2017).

FANFANi A., Cattolicesimo e protestantesimo nella formazione storica del capitalismo, Milano 1934.

GARDAWSKI J., Ewangelicki etos pracy a efektywność makroekonomiczna, „Gdański Rocznik Ewangelicki” 3 (2009), s. 9-28.

Hintz M., Marcin Luter - ojciec etyki ewangelickiej, w: M. Luter, Pisma etyczne, M. Hintz (red.), Bielsko-Biała 2009, s. 7-27.

Hintz M., Teologiczne aspekty ewangelickiego etosu pracy, „Gdański Rocznik Ewangelicki" 3 (2009), s. 29-43.

Huber W., Ethik. Die Grundfragen unseres Lebens von der Geburt bis zum Tod, München 2016.

Luter M., Kleiner Sermon von dem Wucher (1519), https://archive.org/stream/ werkekritischege06luthuoft\#page/2/mode/2up (16.01.2017).

Luter M., Großer Sermon von dem Wucher (1520), https://archive.org/stream/ werkekritischege06luthuoft\#page/36/mode/2up (16.01.2017).

Luter M., O wolności chrześcijańskiej (1520), http://old.luteranie.pl/www/biblioteka/dpisma/luter3.htm (16.01.2017).

LuTER M., Tessaradecas consolatoria pro laborantibus et oneratis (1520), https://archive.org/stream/werkekritischege06luthuoft\#page/98/mode/2up (16.01.2017).

Luter M., Der 127. Psalm ausgelegt an die Christen zu Riga in Ließland (1524), https://archive.org/stream/D.MartinLuthersWerkeWeimarerAusgabeWa15/ Wa15\#page/n355/mode/2up (16.01.2017).

Luter M., O kupiectwie i lichwie (1524), w: M. Luter, Pisma etyczne, M. Hintz (red.), Bielsko-Biała 2009, s. 161-178.

LuTER M., Duży katechizm (1529), w: Księgi Wyznaniowe Kościoła Luterańskiego, Bielsko-Biała 2003, s. 57-131.

Luter M., Der 147. Psalm, Lauda Jerusalem, ausgelegt (1532), https://archive.org/ stream/werkekritischege3101luthuoft\#page/426/mode/2up (16.01.2017). 
Luter M., Viel fast nützlicher Punkt ausgezogen aus etlichen Predigten D. M. Luthers (1537), https://archive.org/stream/werkekritischege45luthuoft\#page/362/mode/2up (16.01.2017)

LuTER M., An die Pfarrherrn wider den Wucher zu predigen (1540), https://archive. org/stream/werkekritischege51luthuoft\#page/324/mode/2up (16.01.2017).

Melanchton F., Wyznanie augsburskie (1530), w: Księi Wyznaniowe Kościoła Luterańskiego, Bielsko-Biała 2003, s. 143-163.

Milerski B., Etos pracy jako postać świadomości protestanckiej, „Gdański Rocznik Ewangelicki” 3 (2009), s. 55-67.

Novak M., Duch demokratycznego kapitalizmu, thum. T. Stanek, Poznań 2001.

Oermann N.O., Anständig Geld verdienen? Eine protestantische Wirtschaftsethik, Freiburg im Br. 2014.

Pawlas A., Die lutherische Berufs- und Wirtschaftsethik. Eine Einführung, Neukirchen-Vluyn 2000.

Sabatini S., Etyka i ekonomia po Weberze, „Społeczeństwo” 20 (2010) nr 6, s. $817-842$.

SzCZEPAŃSKi J., Korzeniami wrostem w ziemię, Ustroń 2003.

SzKARADNIK K., Wspólnota małego miasta a odpowiedzi(alność) wysztudyrowanych - wokót myśli i rodzinnych stron Jana Szczepańskiego, http://www. anthropos.us.edu.pl/anthropos10/texty/szkaradnik.htm (16.01.2017).

Uglonz M.J., Ewangelicki etos pracy w kontekście integralnie pojmowanej ekonomii, http://naszedziedzictwo.blox.p1/2012/11/Ewangelicki-etos-pracy-w-kontekscie-integralnie-1.html (16.01.2017).

Weber M., Etyka protestancka i duch kapitalizmu, tłum. J. Miziński, Lublin 1994. 